\title{
BUSINESS MODEL CANVAS VOLKS.Co FACILITY PEKANBARU
}

\author{
Mutia Ulfah \\ Sekolah Tinggi Ilmu Ekonomi Persada Bunda \\ Jl. Diponegoro No. 42 Pekanbaru \\ E-mail: mutiaulf@gmail.com
}

\begin{abstract}
The most recent studies in urban and creative economics have shown how freelance workers and unstable professionals define by a desire to maintain relationships and conduct social capital beyond their proficient network as a crucial source for upcoming jobs. Both of freelance workers and unstable professional have to evolve self-entrepreneurial habits and comply self-branding approach in a most entrepreneurial outlook. Due to these new work order, a new pattern of work appear in numerous countries around the world as well as Indonesia, popularly known as co-working space. Co-working spaces accommodate a dynamic, creative and cozy work ambience not just for freelancer but also for associated organization. Volks.co as the first co-working space in Pekanbaru needs to adapted some circumstances in Pekanbaru. This study tries to figure out the ability of Volks.co business strategy by using Business Model Canvas (BMC), SWOT Analysis, IPA Matrix as a tool map to review the business strategy of Volks.co. Furthermore, based on the findings there's few things need to improve by Volks.co to keep running and growing the business with in the industry in the future
\end{abstract}

Keywords: Business Canvas, Co-working Space, Business Strategy, Importance-Performance Matrix

Sejalan dengan Program Ekonomi era Jokowi yang menggiatkan ekonomi kreatif untuk kedepannya sebagai tulang punggung dan pilar perekonomian Indonesia. Ekonomi Kreatif dipercaya sebagai kekuatan baru yang potensial untuk menjadi pusat pertumbuhan ekonomi nasional. Perkembangan jumlah pekerja lepas (freelancer) dan perusahaan baru (start-up company) di Indonesia khususnya di Kota Pekanbaru dari tahun ke tahun pun meningkat, memunculkan gaya bekerja yang baru yang lebih bebas, fleksibel dan mandiri, sehingga problematika yang timbul juga berbeda dari pola kerja yang sudah ada sebelumnya.

Deputi Koordinasi Ekonomi Kreatif Kementrian Koordinator Bidang Perekonomian dalam keynote speech-nya pada seminar Ekonomi Berbasis Kreativitas dan Inovasi menyatakan bahwa salah satu upaya untuk menjawab tantangan dan permasalahan dari pola kerja baru yang timbul tersebut adalah dengan menciptakan ruang sebagai pusat aktivitas dan interaksi untuk para pelaku ekonomi kreatif, baik pemerintah, pelaku usaha, industri, akademisi, serta komunitas/forum kreatif. Di satu sisi, ruang kreatif tersebut hendaknya mampu mengkakomodir dan mengilhami munculnya sense of creativity. Di sisi lainnya, ruang tersebut hendaknya mampu menggabungkan proses creation-production-distribution dan pemasaran potensi ekonomi kreatif yang ada. Oleh karena itu ruang kreatif sebaiknya dirancang untuk membentuk iklim dan ekosistem ekonomi kreatif yang comprehensive condusive, partisipative, dan inclusive. (Kementrian Koordinator Bidang Perekonomian, 2015)

VOLKS.Co perusahaan yang bergerak dibidang hospitality dan public relation membuat sebuah inovasi dengan menggabungkan kantor bersama dan coffee shop dalam satu gedung. Volks Facility sebagai coworking space pertama di Pekanbaru menawarkan layanan yang memfasilitasi para pekerja kreatif, komunitas, perusahaan start up atau pun coorporate. Tantangan utama yang dihadapi oleh Volks.co adalah 
memperkenalkan konsep coworking space yang masih baru di mata publik khususnya masyarakat kota Pekanbaru, sehingga tercipta kebutuhan akan coworking space itu sendiri. Walaupun sejatinya, konsep coworking space sudah menjamur di luar negeri bahkan di beberapa kota-kota besar di Indonesia seperti Jakarta, Bandung, dan Surabaya, namun perlu beberapa penyesuaian terkait konsep operasional untuk dijalankan di Pekanbaru. Sehingga diperlukan konsep model bisnis yang tepat untuk dapat menjalankan bisnis coworking space di Kota Pekanbaru.

Berdasarkan hasil laporan survei Khusus Ekonomi Kreatif (2016) jumlah pekerja Indonesia yang berada dalam industri kreatif pada tahun 2015 sampai pada angka 15,95 juta jiwa atau sebesar $14 \%$ dari total penduduk bekerja Indonesia yang mana 92,19\% diantaranya merupakan tenaga kerja Blue Collar. Dimana 75,5\% berada pada status usia 25-29 tahun. Angka tersebut meningkat dari tahun 2006 sampai 2010 di mana hanya tercatat 1,5 juta jiwa. Dari hasil survei SKEK 2016 juga terlihat bahwa Ekonomi Kreatif mampu memberikan kontribusi secara signifikan terhadap pertumbuhan ekonomi nasional sebesar $10,14 \%$ per tahunnya. Riau, menjadi salah satu diantara 10 provinsi penyumbang ekspor ekonomi kreatif di Indonesia. Hal tersebut menunjukkan bahwa ekonomi kreatif di Riau memiliki potensi untuk berkembang di masa mendatang. Tidak dapat dipungkiri bahwa perusahaan yang bergerak dalam industri non-kreatif pun juga membutuhkan tenaga kerja kreatif untuk dapat mengembangkan potensi serta membentuk gambaran tiap perusahaan.

Berdasarkan laporan SKEK 2016 menunjukkan bahwa masih sedikit usaha ekonomi kreatif yang berbadan hukum. Hal ini terindikasi dari banyaknya unit usaha yang memiliki tenaga kerja dibawah orang, dengan kata lain, pekerja industri kreatif di Indonesia masih dominan start-up dan freelancer. Sekitar 20\% pekerja ekonomi kreatif bekerja dengan jam kerja tidak penuh atau kurang dari 35 jam per minggu, di sisi lain sekitar 31,98\% pekerja ekonomi kreatif bekerja dengan jam kerja berlebih yaitu diatas 48 jam per minggu (Bekraf, 2016).

Problem utama yang menjadi kendala bagi para start-up biasanya belum memiliki kantor tetap karena adanya keterbatasan modal. Tempat yang strategis serta dapat dijangkau sekaligus nyaman bagi mereka untuk bekerja bisa menjadi pilihan yang tepat bagi para startup ataupun freelancer. Tentu saja bekerja dari rumah terkadang memiliki kendala bahwa berbagai pertemuan atau meeting menjadi tidak mungkin untuk diadakan di rumah karena alasan tidak layaknya rumah sebagai tempat pertemuan serta lokasi kurang strategis karena di daerah perumahan. Hal inilah yang secara tidak langsung memicu maraknya tren baru untuk melakukan pekerjaan di luar kantor seperti kafe atau tempat lain yang dianggap nyaman. Di sisi lain, alasan utama yang menjadikan ruang publik sebagai ruang kerja adalah karena sulit bagi para pekerja lepas atau pengusaha pemula untuk langsung dapat menyewa ruang kantor dengan fasilitas yang baik dan desain yang menarik di lokasi yang strategis, mengingat keterbatasan modal yang dimiliki.

Mahalnya harga penyewaan tempat untuk bekerja bagi para pengusaha muda juga menjadi masalah lain. Menurut artikel yang ditulis pada Kompas, 22 Febuari 2013, harga sewa kantor di Indonesia mengalami kenaikan rata-rata sebesar $8,5 \%$ per tahun. Cushman dan Wakerfield (2013) dalam artikelnya "Office Space Across the World 2013" juga mengatakan bahwa kenaikan harga sewa kantor di kota kota besar di Indonesia merupakan yang tertinggi seAsia Pasifik.

Walaupun memiliki waktu bekerja yang fleksibel serta lokasi bekerja yang strategis dan dapat disewa dengan harga terjangkau adalah faktor penting, namun nilai kolaborasi dan jaringan yang akan 
terbentuk dari lingkungan bekerja akan menjadi poin yang menarik bagi para freelancer atau start-up. Oleh karena itu, banyak diantara mereka yang membutuhkan tempat nyaman untuk bekerja dengan lokasi yang strategis serta harga yang dapat dijangkau, serta tetap membuka peluang untuk menjalin jaringan (network) dan membentuk kolaborasi. Problematika akan kebutuhan akan ruang tersebut memicu munculnuya konsep pemanfaatan ruang yang dikenal dengan coworking space.

Industri yang ditargetkan sebagai pengguna coworking space adalah para tenaga profesional dalam industri kreatif. Karena, para individu dalam industri kreatif memiliki peluang untuk bekerja sendiri, namun tetap membutuhkan jaringan untuk dapat maju dan berkembang.

Dalam Strategic Management, strategi dipercaya sebagai acuan fundamental suatu bisnis untuk terus melangkah ke depan sehingga dapat meraih goals yang sudah ditetapkan. Termasuk diantaranya adalah keterampilan perusahaan dalam menghadapi tantangan dan kondisi pasar yang baru. Memiliki model bisnis yang baik adalah salah satu satu keharusan agar perusahaan dapat menciptakan nilai tambah sehingga mampu menghasilkan laba. (Ebert dan Griffin , 2015:37)

Osterwalder dan Pigneur (2014) mengatakan bahwa Business Model Canvas (BMC) mampu memaparkan model bisnis yang ada dengan lebih rinci sehingga dapat mengambarkan tentang bagaimana sebuah perusahaan menghasilkan uang, sembilan blok pada Business Model Canvas merangkum empat bidang utama dalam suatu bisnis yaitu pelanggan, produk dan jasa yang ditawarkan, infrastruktur dari bisnis, dan proyeksi kelangsungan keuangan perusahaan.

Business Model Canvas (BMC) merupakan sebuah strategi dalam manajemen berupa visual chart yang dapat digunakan sebagai framework mapping suatu bisnis. Di sisi lain, Business Model
Canvas juga berfungsi sebagai acuan untuk evaluasi model bisnis yang telah berjalan, sehingga tercipta usulan rancangan model bisnis yang baru.

SWOT Analysis merupakan alat bantu yang digunakan untuk mengevaluasi suatu bisnis dengan pemetaan kekuatan, kelemahan, peluang dan ancaman yang ada dari industri sejenis. Analisis SWOT terdiri atas analisis strengths and weakness, analisis opportunities, dan analisis threats yang masing-masing akan mengevaluasi aktivitas bisnis perusahaan yang tergambar pada sembilan blok bisnis model kanvas. Pembagian kelompok analisis ini sesuai dengan pedoman evaluasi Business Model Canvas Osterwalder \& Pigneur (2010) pada buku Business Model Generation.

Porter dalam "Competitive Advantage, 1985" mengajukan model analisis 5 forces sebagai alat untuk menganalisis lingkungan persaingan industri. Analisis Porter merupakan suatu alat yang sederhana namun sangat berguna untuk memahami dimana letak kekuatan perusahaan dalam menghadapi situasi persaingan di dunia bisnis. Dengan mengunakan analisis ini, dapat dipahami kekuatan posisi persaingan saat ini dan kekuatan posisi persaingan pada bisnis yang ada. Sehingga perusahaan dapat meningkatkan kekuatan, mengantisipasi kelemahan dan akan menghindari perusahaan dalam pengambilan keputusan yang salah. Secara konvensional tool ini dapat digunakan untuk mengidentifikasi apakah suatu bisnis dapat menghasilkan suatu keuntungan. Tapi selain itu akan sangat membantu untuk mengerti keseimbangan kekuatan yang berpengaruh dalam situasi bisnis yang sedang dihadapi. (Porter, 2008)

\section{Importance-Performance Analysis} (IPA) Matrix merupakan alat yang digunakan untuk mengidentifikasi dan mempertimbangkan kekuatan dan kelemahan bisnis perusahaan secara simultan pada tahap penetapan ataupun 
evaluasi strategi perusahaan guna meningkatkan perfomansi perusahaan. (Chen dan Lin, 2014)

Berikut adalah tahapan dari penelitan ini:

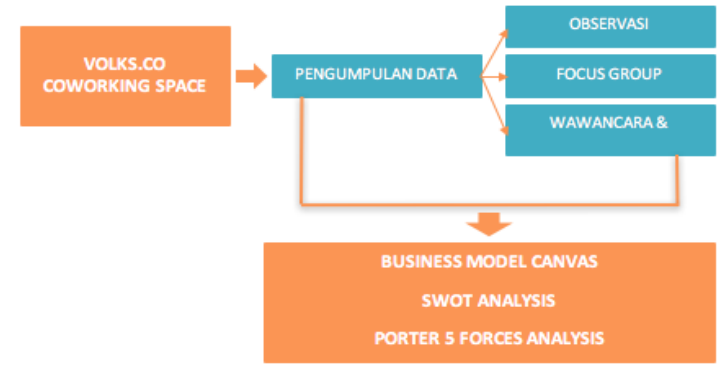

sumber: Olahan Penulis (2018)

\section{METODE}

Penelitian ini menggunakan pendekatan deskriptif kualitatif. Pendekatan ini dipandang lebih relevan untuk memperoleh fakta-fakta dari fenomena yang ada serta dapat menggali keterangan secara faktual dari suatu kelompok masyarakat dengan cara sensus ataupun sampling. Sehingga tidak hanya memberikan gambaran terhadap fenomena tetapi juga menerangkan hubungan dari suatu masalah yang ingin dipecahkan. Objek pada penelitian ini adalah Volks.Co Facility di Pekanbaru. Sedangkan subjek / narasumber dari penelitian terbagi atas: Narasumber Internal adalah pihak Volks.Co. Narasumber Eksternal adalah pelanggan/members Volks.Co.

\section{HASIL}

Analisa SWOT dalam Kategori Industri, Berikut penulis mencoba untuk menganalisa kafe dan kedai kopi dan Volks.Co Facility. Hasil dari wawancara terhadap beberapa responden dan juga pemilik gerai waralaba dipaparkan sebagai berikut:

a. trength: Lokasi di mall dan tempat strategis lainnya dengan berbagai desain ruangan yang unik dan menarik mampu menarik pelanggan untuk lebih memilih kafe dan kedai kopi untuk melakukan pekerjaan mereka.

b. Weakness

- Fasilitas yang kurang memadai untuk bekerja.
- Suasana terlalu gaduh karena kafe dan kedai kopi tidak hanya digunakan untuk bekerja namun juga untuk para pelanggan lain menghabiskan waktu luang mereka dengan bertemu kerabat

c. Opportunity: Budaya kafe dan kedai kopi masih menjadi tren; banyak masyarakat yang menganggap melakukan pekerjaan di kafe dan kedai kopi sebagai sebuah tren. Penduduk di Pekanbaru suka mencoba hal baru / latah

d. Threat: Pertumbuhan kafe dan kedai kopi yang semakin menjamur setiap tahunnya membuat persaingan menjadi lebih kompetitif

\section{Analisa SWOT Volks.co}

a. Strength

- Bangunan yang ditempati oleh Volks.Co merupakan kepemilikan sendiri (Ruko Pribadi)

- Volks.Co merupakan coworking space komersil pertama di Pekanbaru dengan review rate sebesar 4,3 pada google bisnis.

- Tempat dan Coffee yang ditawarkan dinilai baik oleh pelanggan

- Fasilitas kerja yang disediakan cukup memadai dan nyaman dengan desain industrial yang cukup menarik di mata pelanggan

b. Weakness

- Ruangan terbatas. Ruangan kerja di area public space dapat digunakan untuk events untuk kapasitas maksimal 25 orang

- Tidak ada sekat smoking area, pelanggan mengharapkan ruang coworking yang bebas asap rokok dan full AC

- Sistem pendaftaran dan booking ruangan masih offline. Kuota untuk pelanggan terbatas dengan jumlah meja dan kursi serta kapasitas ruangan

- Masyarakat Kota Pekanbaru masih awam dengan konsep coworking space

- Working space area hanya 
berkonsep industrial, kurang inspiratif bagi para pekerja kreatif. Tidak ada fasilitas pelengkap lain berupa printer/scan yang terintegrasi dengan teknologi

- Lokasi Volks.co dinilai tidak strategis, sehingga banyak pelanggan yang lebih memilih untuk memanfaatkan kedai kopi/café waralaba

\section{c. Opportunity}

Pelanggan bersedia membayar lebih untuk fasilitas yang lebih baik dan benefit yang lebih banyak. Dengan peningkatan jumlah freelancer dan start-up di Pekanbaru, Volks.co dapat memanfaatkan posisi mereka sebagai market leader di Pekanbaru untuk promosi

- Peningkatan jumlah freelancer di Indonesia yang meningkat dari tahun ke tahun. Terbukti Riau menjadi salah satu diantara 10 provinsi penyumbang ekspor eknomi kreatif di Indonesia. Hal ini membuktikan bahwa ekonomi kreatif di Riau memiliki potensi untuk berkembang di masa mendatang

- Peningkatan jumlah startup di Indonesia, menurut startupranking.com yang meningkat menjadi 1024 startup di tahun 2016, dengan sumber daya dan kolaborator yang dimiliki maka Volks.Co dapat melakukan pendekatan untuk pengenalan konsep dan fungsi coworking pada beberapa universitas di Pekanbaru

- Pelanggan membutuhkan pilihan ruangan yang lebih banyak

- Terdapat beberapa universitas dan sekolah tinggi di Pekanbaru yang memiliki fokus Kewirausahaan, sehingga mahasiswa dapat menjadi calon pelanggan setelah mereka lulus dari universitas, khususnya mahasiswa yang tertarik bekerja di lingkungan industri kreatif dan menjadi pekerja mandiri

\section{d. Threats}

- Pertumbuhan kafe dan kedai kopi yang semakin menjamur setiap tahunnya membuat persaingan menjadi lebih kompetitif. Sehingga menjadi substitusi dari coworking space itu sendiri

- Pesaing seperti café dan kedai kopi waralaba menawarkan harga yang lebih murah dan tempat yang lebih nyaman (Non Smoking Area + Full $A C)$

- Pangsa pasar coworking space sensitif terhadap harga

\section{Analis a Porter's Five Forces}

\section{Bargaining Power of Buyer}

Target Buyer dari coworking space sendiri adalah pekerja freelance dan start-up di bidang kreatif yang hingga saat ini di Indonesia berjumlah 8,5 juta jiwa. Karena coworking space merupakan konsep baru, maka daya tawar pembeli masih tergolong rendah.

2. Bargaining Power of Supplier

Seperti yang telah dijelaskan, bahwa daya tawar penjual dapat dikategorikan tinggi atau rendah tergantung dari jumlah supply dan demand penjual produk yang mirip atau sama. Jika banyak yang menjual produk yang sama atau mirip maka daya tawar penjual akan rendah. Coworking space di Pekanbaru masih tergolong industri baru, oleh karena itu daya tawar jual tergolong tinggi.

3. Threat of New Entrants

Konsep dari coworking space hanya memerlukan kapital sebesar US $\$ 58,000$ untuk kawasan US dan berkisar di $€ 46,500$ di kawasan Eropa (Deskwanted, 2010). Sehingga apabila berhasil, akan menarik pesaing baru dengan mudah.

4. Threat of Substitute Product

Produk pengganti yang utama adalah kafe, dan kedai kopi. Banyaknya kafe dan kedai kopi menyebabkan lebih mudah dijangkau oleh para pelanggan menyebabkan produk pengganti tergolong cukup tinggi. Ancaman terhadap produk pengganti dapat terjadi

p.ISSN: $2407-800 \mathrm{X} \quad$ e.ISSN: $2541-4356$ 
bila coworking space memiliki harga yang terlalu mahal, kualitas sudah tidak seperti yang diharapkan oleh konsumen. Untuk saat ini ketidaknyamanan dan fasilitas yang kurang mendukung, serta tidak adanya peluang untuk berinteraksi, berkolaborasi, terlebih lagi partnering di kafe dan kedai kopi menyebabkan produk pengganti menjadi tergolong moderate.

5. Rivalry Among Existing Competitor

Seperti telah dijelaskan sebelumnya, pesaing akan datang dari pesaing tidak langsung yakni kafe dan kedai kopi. Karena target utama dari pengunjung sebagian besar merupakan pekerja, freelance ataupun start-up business di bidang industri kreatif yang sebelumnya biasa menjadikan kafe dan kedai kopi sebagai meeting point ataupun tempat bekerja. Karena barunya kategori ini, persaingan belum terlalu besar.

Analisa Business Model Canvas

\begin{tabular}{|c|c|c|}
\hline & Kafe \& Kedai Kopi & Volks. Coworking Space \\
\hline $\begin{array}{l}\text { Value } \\
\text { Proposition }\end{array}$ & $\begin{array}{l}\text { Menggabungkan antara kualitas } \\
\text { kopi yang baik, service, dan } \\
\text { atmosfir }\end{array}$ & $\begin{array}{l}\text { Fasilitas bagi para pekerja independen/start-up } \\
\text { yaitu ruang untuk berdiskusi dan bekerja }\end{array}$ \\
\hline $\begin{array}{l}\text { Customer } \\
\text { Segment }\end{array}$ & $\begin{array}{l}\text { Pria dan Wanita umur } 18-43 \\
\text { tahun; pendapatan menengah } \\
\text { keatass; suka bersosialisasi. }\end{array}$ & $\begin{array}{l}\text { Generation } Y(20-35 \text { tahun), pekerja independen/ } \\
\text { freelance, mobile. }\end{array}$ \\
\hline Channels & $\begin{array}{l}\text { Perkantoran, Mall, dan beberapa } \\
\text { Rumah Sakit }\end{array}$ & $\begin{array}{l}\text { Lokasi dinilai kurang strategis dan tidak banyak } \\
\text { yang tahu }\end{array}$ \\
\hline $\begin{array}{l}\text { Customer } \\
\text { Relationship }\end{array}$ & $\begin{array}{l}\text { Mengingat nama para pelanggan } \\
\text { yang memesan kopi. }\end{array}$ & Host dan Member, namun belum efektif \\
\hline $\begin{array}{l}\text { Revenue } \\
\text { Str. }\end{array}$ & \begin{tabular}{|l|} 
Penjualan minuman dan snack \\
\end{tabular} & Cover charge working space \\
\hline $\begin{array}{l}\text { Key } \\
\text { Resources }\end{array}$ & $\begin{array}{l}\text { Kualitas kopi yang baik, servis } \\
\text { yang konsisten, dan atmosfir yang } \\
\text { nyaman }\end{array}$ & $\begin{array}{l}\text { suasana dinamis \& kondusif namun tidak } \\
\text { inspiratif beberapa pelanggan menyukai } \\
\text { pelayanan dan produk olahan dari Volks Koffie }\end{array}$ \\
\hline $\begin{array}{l}\text { Key } \\
\text { Activities }\end{array}$ & $\begin{array}{l}\text { Menjual produk kopi beserta } \\
\text { makanan kecil yang dilengkapi } \\
\text { dengan tempat yang nyaman, dan } \\
\text { internet sehingga membuat para } \\
\text { pelanggan merasa nyaman } \\
\text { menghabiskan waktu disana }\end{array}$ & $\begin{array}{l}\text { Penyedia ruangan untuk bekerja dan rapat di } \\
\text { lantai atas, fasilitas kedai kopi pada lantai dasar }\end{array}$ \\
\hline $\begin{array}{l}\text { Key } \\
\text { Partnership }\end{array}$ & $\begin{array}{l}\text { Promo Kartu Kredit Perbankan } \\
\text { buy 1 get I or upgrade }\end{array}$ & Komunitas, Vendor Internet, Vendor Elektronik \\
\hline $\begin{array}{l}\text { Cost } \\
\text { Structure }\end{array}$ & $\begin{array}{l}\text { Franchise fee, pembelian bahan } \\
\text { yang digunakan, pembelian } \\
\text { mesin, penyewaan tempat, } \\
\text { pembelian perlengkapan, dan gaji } \\
\text { karyawan. }\end{array}$ & $\begin{array}{l}\text { Pengadaan acara, penyewaan tempat, } \\
\text { pembelian mesin dan furniture, pembelian } \\
\text { perlengkapan, biaya listrik/airftelepon, gaji } \\
\text { karyawan. }\end{array}$ \\
\hline
\end{tabular}

Analisa IPA Matrix

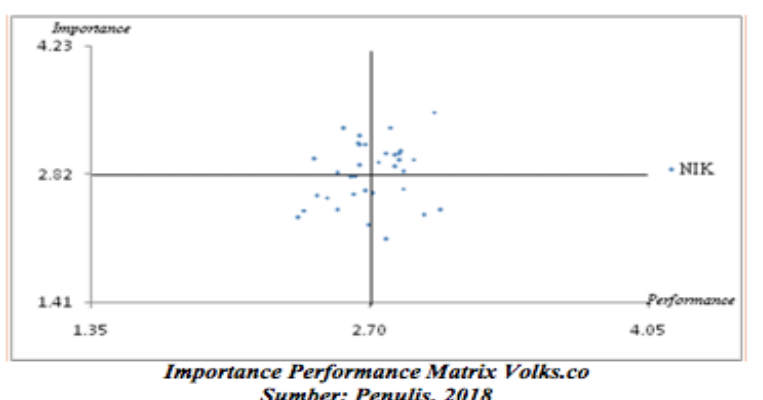

Sumber: Penulis, 2018
Dari evaluasi yang telah dilakukan dapat dilihat bahwa hampir seluruh atribut merata pada Kuadran I, II, dan III. Berdasarkan pemetaan matrix Importance Performance Volks.co diatas, dapat disimpulkan bahwa Volks.co sudah cukup baik dalam menjalankan bisnis coworking space. Tapi, perlu kiranya peningkatan kinerja pada atribut yang berada di kuadran I.

\section{PEMBAHASAN}

Berdasarkan data di lapangan dan analisis yang sudah dilakukan pada penelitian ini, maka kesimpulan yang dapat menjawab rumusan masalah yakni : Business Model Coworking space Volks.Co sudah sesuai dengan standar Business Model Canvas Osterwalder \& Pigneur

i. Customer Segments - Volks.Co belum memiliki customer segment yang jelas. Freelancer dan Teleworkers yang menjadi target belum dibidik secara tepat. Berdasarkan focus group discussion yang penulis lakukan, sebaiknya segmen pasar dari Volks.co diberi special offering berupa membership plans sesuai dengan kebutuhannya.

ii. Value Proposition - sejak awal Volks.co memang belum memiliki value proposition yang membedakannya dari pesaing sejenis. Volks.Co hanya menjual pelayanan penyewaan ruang kerja sebatas meja dan ruang meeting untuk events. Dengan jumlah kursi terbatas pada lantai 2 ruko bertingkat.

iii. Channels - Volks.co belum bersungguh-sungguh dalam menentukan proposisi nilainya dan segmen pelanggannya, begitu pula halnya dengan saluran yang digunakan, hanya sebatas social media dan events pasif. 
Dari hasil evaluasi ImportancePerformance Analysis Matrix, sebaiknya dilakukan peningkatan pada kinerja atribut yang berada di tingkat performansi pada kuadran I yakni sebagai berikut:

a) Kelengkapan fasilitas; fasilitas yang ditawarkan dirasa pelanggan masih belum memuaskan. Hanya sebatas meja kecil layaknya meja di kafe/kedai kopi waralaba. Tidak ada fasilitas khusus yang membedakan Volks.co sebagai coworking space dengan kafe/kedai kopi. Responden mengharapkan Points-of-Difference (POD) atau poin yang membedakan Volks.co dengan para kompetitor secara langsung dan tidak langsung adalah coworking space mampu menawarkan kesempatan partnering bagi para freelance dan start-up bisnis dengan memfasilitasi kebutuhan mereka untuk membangun bisnisnya. Interaksi, kolaborasi, serta networking

b) Jasa yang ditawarkan sesuai dengan kebutuhan pelanggan (jenis, kualitas, maupun harga); Points-of-Parity (POP) atau poin yang patut dimiliki oleh Coworking Space adalah ruang kerja dan rapat pada lokasi strategis atau one stop shopping, online booking service, perpusatakaan mini, personal assistant (upon request), fasilitas standar kantor (mesin print, fax, fotokopi, serta proyektor), virtual office, alat tulis atau stationery, unlimited broadband internet service, sumber listrik, dedicated toilet.

c) Lokasi yang kurang strategis; responden menilai lokasi Volks.co saat ini tidak begitu strategis. Beberapa dari responden lebih memilih untuk memanfaatkan kedai kopi waralaba seperti Starbucks karena berada di tengah dan pusat kota. Serta mudah ditemukan.

d) Kesulitan memperoleh informasi pada brosur, iklan, poster dan lain-lain; responden mengakui kurangnya promosi yang dilakukan Volks.co baik dari iklan, brosur ataupun poster di social media maupun media offline lainnya.

e) Kesesuaian jenis jasa yang ditawarkan dengan yang diinformasikan; beberapa responden mengaku kurang puas dengan fasilitas yang ditawarkan Volks.co sebagai coworking space. Ruang kerja yang kecil, serta tidak adanya sekat ruangan untuk no smoking area. Begitupula halnya dengan networking dan kolaborasi yang pernah diutarakan pada saat grand opening, responden mengaku tidak merasakan adanya networking dan kolaborasi yang terjalin setelah beberapa kali menggunakan fasilitas Volks.co, justru hanya sekedar ruang kerja saja tidak lebih.

f) Kesesuaian harga dengan kualitas pelayanan dan jasa; responden mengaku keberatan dengan tariff per jam yang diterapkan terkait kualitas pelayanan dan jasa yang ditawarkan. Tarif penyewaan ruang tidak sesuai dengan pelayanan yang didapatkan.

g) Daya tarik desain interior ruangan; responden mengaku konsep industrial yang diusung oleh Volks.co sudah cukup menarik, hanya saja tidak terlalu inspiratif karena terkesan monoton dan tidak memberi percikan imajinasi bagi freelancer di industri kreatif.

h) Daya tarik tampilan luar gedung; responden mengaku selain lokasi yang kurang strategis, tampilan luar gedung Volks.co juga kurang menarik atau tidak eye-catchy, sehingga cukup sulit untuk ditemukan, dan membuat kekuatan akan nilai jual brand Volks.co sendiri menjadi lemah di mata pelanggan. 


\section{SIMPULAN}

Berdasarkan hasil penelitian serta analisis yang ada, maka kesimpulan yang di dapat untuk menjawab rumusan masalah penelitian yakni sebagai berikut: ís?

1. Hasil pemetaan 9 block business model Canvas Volks.co, Volks.co dirasa belum mampu memperlihatkan konsep ide bisnis Volks.co sepenuhnya, konsep Volks.co sebagai coworking space dirasa belum cukup terstruktur. Melalui desk research dan analisis klasik lainnya penulis melakukan rekomendasi beberapa perubahan model bisnis coworking space yang dijalani Volks.Co. seperti tertuang pada Gambar 6.

2. Volks.co sebagai coworking space pertama di Kota Pekanbaru telah menjalankan bisnisnya sesuai dengan visi misi namun berdasarkan pemetaan matrix Importance Performance Volks.co dapat disimpulkan bahwa dalam menjalankan bisnis coworking space nya masih belum terlalu fokus, beberapa atribut cenderung menyebar di kuadran yang perlu ditingkatkan lagi. Sehingga untuk perkembangan kedepannya dirasa perlu untuk mempertimbangkan saran-saran dari pihak internal maupun eksternal agar Volks.co mampu bersaing dan berkembang.

\section{DAFTAR RUJUKAN}

Armour, S. (2011). Generation Y: They've Arrived at Work with a New Attitude. USA Today.

Badan Ekonomi Kreatif. (2016). Hasil Survey Ekonomi Kreatif. Jakarta

Chen, Y. C. dan Lin, S. (2013). Applying Importance-Performance Analysis for Improving Internal Marketing of Hospital Management in Taiwan.
International Business Research. Vol. 6, No. 4; 2013

Coworking: Find Coworking Spaces and Meeting Rooms. (2010). Retrieved Mei 11, 2017, from Deskwanted.com: https://www.desk wanted.com/about/how-do-i-start-acoworking-space.html

Cushman, J. C., \& Wakefield, B. (2012, December). Office Space Across the World 2013. p.20.

Departemen Perdagangan Republik Indonesia. (2008). Pengembangan Ekonomi Kreatif Indonesia 2025. Jakarta: Departemen Perdagangan Republik Indonesia.

Euromonitor. (2010). Indonesia - The Food Service Industry. Canada: International Market Bureau.

Ebert, Ronald J. and Griffin, Ricky W. (2015). Business Essentials. (10th ed). Essex, England: Pearson Education Limited

Foertsch, C. (2011). The Cultural Background of Coworking. Retrieved April 27, 2018, from DeskMag:

http://www.deskmag.com/en/whatis-coworking-about-the-changinglabor-market-208

Friedersdorf, C. (2011). Working Best at Kedai Kopi. Retrieved April 29, 2018, from The Atlantic: http://www.theatlantic.com/business /archive/2011/04/working-best-atcoffee-shops/237372/

Indrawati. (2015). Metode Penelitian Manajemen dan Bisnis Konvergensi Teknologi Komunikasi dan Informasi. Bandung: PT. Refika Aditama

IPSOS. (2011). Telecommuting - Citizens in 24 Countries Assess Working Remotely for a Total Global Perspective. Paris, France: IPSOS

Kementrian Koordinator Bidang Perekonomian. (2015). Ekonomi Berbasis Kreativitas dan Inovasi sebagai Kekuatan Baru Ekonomi Indonesia. 
https://www.ekon.go.id/berita/view/e

konomi-berbasis-

kreativitas.1659.html. Akses 5

Desember 2017

Kurtz, D. L. (2008). Principles of Contemporary Marketing. SouthWestern Cengage Learning.

Matos, K., \& Galinsky, E. (2011). Work Place Flexibility in US: A Status Report. Society for Human Resources Management.

Osterwalder, A., \& Pigneur, Y. (2010). Business Model Generation. USA: John Wiley and Sons.

Pangestu, M. E. (2008). Pengembangan Ekonomi Kreatif Indonesia 2025: HASIL KONVENSI PENGEMBANGAN EKONOMI KREATIF 2009-2015. Jakarta: Departemen Perdagangan Republik Indonesia.

Putri, Lira Parahita Agni. (2016). Studi Model Bisnis Coworking Space Di Kota Bandung Menggunakan Bisnis Model Canvas. Jurnal Demandia Vol.1 No.2 : 183-201

Porter, Michael E. (2008). The Five Competitive Forces that Shape Strategy. Harvard Business Review.

Ulfah, Mutia (2018). Studi Model Bisnis Coworking Space di Kota Pekanbaru. Jurnal Daya Saing Vol. 4 No. 2, Juni 2018.

Warta Ekonomi. (2013). “Cushman \& Wakefield: Pertumbuhan Harga Sewa Kantor di Jakarta Paling Tinggi di Asia Pasifik" Akses 15 Maret 2018. <http://wartaekonomi.co.id/berita802 9/cushman--wakefield-pertumbuhanharga-sewa-kantor-di-jakarta-palingtinggi-di-asia-pasifik.html> 